\title{
Translation and cultural adaptation of the Needs of Parents Questionnaire (NPQ) to be used in Brazil
}

\author{
Tradução e adaptação cultural do Needs of Parents Questionnaire (NPQ) para uso no Brasil \\ Traducción y adaptación cultural del Needs of Parents Questionnaire (NPQ) para uso en Brasil
}

\author{
Rosyan Carvalho Andrade ${ }^{1}$ \\ Ana Carolina Andrade Biaggi Leite ${ }^{1}$ \\ Willyane de Andrade Alvarenga ${ }^{1}$ \\ Rafael Rozeta Martimiano ${ }^{1}$ \\ Claudia Benedita dos Santos ${ }^{1}$ \\ Lucila Castanheira Nascimento ${ }^{1}$
}

1. Universidade de São Paulo.

Ribeirão Preto, SP, Brazil.

\section{Abstract}

Objective: To translate, culturally adapt, and assess the internal consistency of the adapted version of the Needs of Parents Questionnaire (NPQ) to be used in Brazil with a sample of parents of hospitalized children. Method: Methodological study, essentially based on the DISABKIDS ${ }^{\circledR}$ method and conducted in a public university hospital. The stages included translation, assessment by an expert committee, back translation, semantic validation, and pilot study. Results: After the original instrument was translated into Brazilian Portuguese and then back-translated, the semantic validation was performed with 30 parents and adjustments were implemented until the translated version was understandable by most participants. Afterwards, a pilot test was implemented with another 59 parents, the internal consistency of which was satisfactory. Conclusions: The Brazilian version of the NPQ proved to be reliable and, after assessing other psychometric properties in the field study, it will be useful to assess the needs of parents of hospitalized children, qualifying nursing care.

Keywords: Child, Hospitalized; Parents; Needs; Validation Studies; Pediatric Nursing.

\section{Resumo}

Objetivo: Realizar a tradução, adaptação cultural e avaliação da consistência interna da versão adaptada do Needs of Parents Questionnaire (NPQ) em amostra de pais de crianças hospitalizadas no Brasil. Método: Estudo metodológico, fundamentado essencialmente no método DISABKIDS $^{\oplus}$, desenvolvido em hospital público universitário. Foram realizadas as etapas de tradução, avaliação por um comitê de especialistas, retrotradução, validação semântica e estudo-piloto. Resultados: Após os processos de tradução e retrotradução do instrumento original para o português do Brasil, procedeu-se à validação semântica com 30 pais, tendo sido realizadas adequações até que a versão traduzida fosse considerada compreensível pela maioria dos participantes. $\mathrm{Na}$ sequência, realizou-se estudo-piloto com outros 59 pais, cujos valores da consistência interna foram satisfatórios. Conclusões: O NPQ adaptado para o Brasil mostrou-se confiável e, após avaliação de outras propriedades psicométricas no estudo de campo, poderá ser útil para avaliar as necessidades de pais de crianças hospitalizadas, qualificando o cuidado de enfermagem.

Palavras-chave: Criança Hospitalizada; Pais; Determinação de Necessidades de Cuidados de Saúde; Estudos de Validação; Enfermagem Pediátrica.

\section{REsumen}

Objetivo: Realizar traducción, adaptación cultural y evaluación de la consistencia interna de la versión adaptada del Needs of Parents Questionnaire (NPQ) en muestras con padres de niños hospitalizados en Brasil. Método: Estudio metodológico, fundamentado esencialmente en el método DISABKIDS ${ }^{\circledR}$, desarrollado en hospital público universitario. Fueron realizadas etapas de traducción, evaluación por un comité de expertos, retrotraducción, validación semántica y estudio piloto. Resultados: Después del proceso de traducción y retrotraducción del instrumento original para el portugués, se produjo la validación semántica con 30 padres, realizándose adecuaciones hasta que la versión traducida fuera considerada comprensible por la mayoría. Después, fue realizado el estudio piloto con otros 59 padres, presentando valores satisfactorios de la consistencia interna. Conclusiones: $E$ NPQ adaptado se demostró confiable y, después de la evaluación de propiedades psicométricas en el estudio de campo, podrá ser útil para evaluar las necesidades de padres de niños hospitalizados, cualificando el cuidado de enfermería.

Palabras clave: Niño Hospitalizado; Padres; Determinación de Necesidades de Cuidados en Salud; Estudios de Validación; Enfermería Pediátrica.
Corresponding author:

Lucila Castanheira Nascimento.

E-mail: lucila@eerp.usp.br

Submitted on $05 / 11 / 2017$.

Accepted on 09/23/2017.

DOI: 10.1590/2177-9465-EAN-2017-0104 


\section{INTRODUCTION}

The hospitalization of a child is a stressful event that causes changes in the family structure and organization. ${ }^{1,2}$ When admitted into a hospital, a child is exposed to a hostile environment where $s / h e$ is subject to painful and potentially traumatic stimuli. The parents, in addition to this unfamiliar, unpleasant and considerably technical environment, simply having a child sick, coupled with the uncertainty and uneasiness caused by the situation, also have to deal with distress, ${ }^{3}$ which makes them feel increasingly helpless. ${ }^{4}$

Additionally, during this time, not only is the child's routine changed, but also the routine of the entire family, whose members need to adapt to various changes, especially in regard to their priorities, values, and the role of each. ${ }^{4}$ Family members may experience loss of autonomy and increased anxiety, which impacts the family who will present needs the healthcare staff needs to promptly identify and meet. ${ }^{4-6}$ Having significant individuals accompany the child, including the parents, at the time of the child's admission is essential for her/his recovery, as this minimizes stressful factors, helping children cope with fear and pain triggered by the process, ${ }^{4-6}$ as the parents know their child's needs and how to satisfy them. ${ }^{7}$

After the Report on maternal deprivation, which was published in 1951 by the World Health Organization, addressing maternal deprivation as an etiological factor affecting one's mental health, in addition to the publication of the Platt Report in 1959 , a new view was established in regard to the hospitalization of children. ${ }^{5,8-10}$ In addition to such milestones in the history of care provided to hospitalized children, the right to have a companion in pediatric wards became law in Brazil on July $13^{\text {th }}$ 1990. Law No. 8069 regulates the Child and Adolescent Statute and establishes in Article 12 that "... health facilities must provide conditions for the full-time stay of a parent or guardian in the event of the hospitalization of children or adolescents". ${ }^{11}$

Since that time, the full-time presence of parents in wards has been a great challenge for the health staff, because in addition to children, the parents, who also need to establish coping strategies to adjust and regulate their emotions and adapt to the experience of hospitalization, need to be included in the care routine. ${ }^{1}$

The parents' psychosocial health is determinant for the physical and mental health of their children, as well as their attitudes toward the disease, especially during hospitalization, also influencing treatment adherence and the impact of the disease on the child. ${ }^{7}$ Even though, healthcare workers play an important role in the assessment and establishment of a care plan based on the child's and family's needs, ${ }^{5}$ the literature shows that they are not always attentive and prepared to provide care to parents and meet their needs from the philosophical perspective of family-centered care, ${ }^{3}$ as they do not exactly know what the feelings and needs of parents are. ${ }^{12}$
Considering that standardized classifications, scales and instruments are firmly integrated into nursing research and clinical practice, ${ }^{13}$ as these strongly influence decisionmaking regarding health care and interventions, ${ }^{14}$ we sought an instrument that would aid healthcare workers and researchers in accessing and assessing such needs. Indicators that express the extent to which the needs of parents have been identified and that provide a descriptive image of the state of art, help to direct health workers toward the identification of interventions able to meet such needs. ${ }^{15}$ No specific validated instrument that meets this objective was found in Brazil. In the international literature, there is the Needs of Parents Questionnaire (NPQ), ${ }^{16,17}$ which was developed by the Icelandic author Gudrún Kristjánsdóttir in the 1980s. It is a relevant instrument because it encompasses the main needs presented by parents who accompany their children during hospitalization, is applicable to any group of parents of hospitalized children, regardless of the reason for hospitalization or diagnosis, and, finally, enables assessing the perceptions of parents regarding their own needs in terms of level of importance, satisfaction and independence in regard to the hospital.

Additionally, the NPQ has been used in various countries developing research related to this theme, such as Iceland, ${ }^{16,17}$ Sweden, ${ }^{18}$ England, ${ }^{19}$ Australia, ${ }^{20}$ Greece, ${ }^{21}$ Mozambique ${ }^{22}$ and Portugal, ${ }^{23,24}$ reaffirming its relevance and importance globally. In this sense, this study's objective was to translate and culturally adapt the instrument, and also assess the internal consistency of the adapted version of the Needs of Parents Questionnaire (NPQ) with a sample of parents of hospitalized children in Brazil.

\section{METHOD}

Methodological study with a cross-sectional design concerning the cultural adaptation and assessment of the internal consistency of the adapted version of the NPQ instrument among Brazilian parents of hospitalized children. The methodological stages of this study followed the recommendations of the DISABKIDS ${ }^{\circledR}$ group, ${ }^{25}$ with one change that consisted of submitting the synthesis of the independent translations to an expert committee ${ }^{26}$ before performing the back translation. Therefore, the stages followed were: translation; expert committee assessment; back translation; semantic validation; and pilot-test applied to a sample of the target population to assess the instrument's internal consistency. The stage concerning psychometric properties, necessary to conclude the validation process, will be performed later.

Parents of hospitalized children and adolescents were invited to take part in this study and were recruited in the pediatric clinic of a university hospital in the interior of the state of São Paulo, Brazil. Inclusion criteria were: parents and/or the primary caregivers of children and adolescents aged between zero and 18 years old, hospitalized for at least 48 hours in the pediatric clinic of the selected facility, who were accompanying 
children during hospitalization for at least six daily hours, actively participating in the care of the hospitalized child. Exclusion criteria were: parents and/or caregivers younger than 18 years old or who did not present minimum conditions necessary to understand the instrument, an aspect assessed by the researchers and after consultation with the healthcare staff, rather than by applying any specific document to assess one's level of comprehension.

Permission to culturally adapt the NPQ was asked of the author of the original version, Gudrún Kristjánsdóttir, after which the project was submitted to and approved by the Institutional Review Boards at the university and hospital, in accordance with Resolution 466/2016 (CAAE:16149913.1.0000.5393). All the participants signed two copies of free and informed consent forms and were assured of their confidentiality.

Needs of Parents Questionnaire:The NPQ was developed by Gudrún Kristjánsdóttir in the 1980s to identify the perceptions of parents regarding their needs during the hospitalization of their children, as well as their levels of satisfaction and independence. ${ }^{16,17}$ It is composed of 71 items organized into three parts. The first part contains 51 items that express aspects regarding the needs of parents, which are distributed into six categories: need to trust; need to be reliable; need for information; need for support and guidance; needs concerning physical and human resources; needs of the child and of other family members. There are three questions for each item that correspond to three scales (A-importance; B-satisfaction; and C-Independence). The items in subscales $A$ and $B$ are scored on a Likert scale, while subscale $C$ presents a dichotomous answer (Yes or No). The second part is composed of questions regarding the instrument itself (general impression), while the third part is composed of questions addressing the participants' sociodemographic data.

Translation, cultural adaptation, and data analysis: The first stage included the translation of the original instrument, initially developed in Iceland, ${ }^{16,17}$ from English to Brazilian Portuguese by two independent Brazilian translators fluent in both languages and experience in the validation of instruments and research in this specific theme. Afterwards, meetings and discussions were held with the researchers and the first reconciled translation was established.

The instrument's reconciled translated version was submitted to an expert committee, using a form developed by these authors based on semantic, idiomatic, cultural and conceptual equivalences. ${ }^{27}$ Five experts from the field of pediatric and family nursing, with academic and clinical experience and proficient in the instrument's original language (English), were invited to compose the committee. This committee worked through both email and mail and the researchers later analyzed their assessments. Approval of changes proposed by the experts obtained agreement of at least $80 \% .{ }^{28}$

Afterwards, the consensual version that resulted from the experts' analyses was back-translated to English by a bilingual translator with vast knowledge of both English and Brazilian Portuguese, who had not had previous contact with the original instrument and was unaware of the subject matter. The backtranslated version was sent to the author of the original version and, after gaining her permission, it was submitted to semantic validation.

In the phase of semantic validation, the participants responded to questions addressing sociocultural data according to a questionnaire developed by the researchers and the translated version of the NPQ, composed of 71 items. The researcher interviewed the participants using two forms developed by the DISABKIDS ${ }^{\circledR}$ group, translated and validated for Brazil. ${ }^{29}$ One form assessed the general impressions of parents regarding the instrument and the other assessed acceptance, relevance, and understanding of the items, designated for each group. The interviews were recorded after acquiring the participants' consent and transcribed verbatim for later analysis.

For this assessment, the instrument was divided into subsets of items and two levels of education were considered for the parents (primary school and high school), while each had at least three parents, as recommended by the DISABKIDS ${ }^{\circledR}$ manual. ${ }^{30}$ Each group answered from 12 to 13 questions, while 24 parents were invited for this first step of the semantic validation. The participants' answers to the characterization questionnaires and semantic assessment were entered into an Excel database (Microsoft Office 2010) for the purpose of coding the variables. Data were double entered to minimize errors in data processing, then, the data were exported to the Statistical Package for the Social Sciences (SPSS), version 16.0, in order to perform the statistical analyses. Descriptive analysis of simple frequency was performed for the categorical variables and central tendency and variability measures were used for the continuous variables that concerned sociocultural data.

After semantic validation, a pre-test was performed with the last translated version adapted to Brazilian Portuguese (pilot test), which in Portuguese was called "Instrumento de Necessidades dos Pais" INP-Brasil, to assess its internal consistency. A total of 59 parents were interviewed considering guidance provided by Sapnas \& Zeller, ${ }^{31}$ which establishes 50 as the minimum number of participants appropriate for assessing the initial psychometric characteristics of an instrument. Descriptive analysis of simple frequency was performed for categorical variables and central tendency measures (mean and median) and variability (standard deviation) for continuous variables concerning sociocultural data. The statistical method used to calculate the psychometric property concerning the reliability of the instrument's translated version was internal consistency verified by Cronbach's alpha test for multi-items variables $^{32}$ and the Kuder Richardson test for dichotomous variables, ${ }^{33}$ such that values considered valid were those greater than 0.70 , as defended by Terwee and colleagues. ${ }^{34}$ 


\section{RESULTS}

Translation, Expert Committee and Back Translation: The translations concerning the NPQ performed by two independent translators were reconciled and then submitted to an expert committee composed of five researchers, who are nurses and professors, with experience in the field of pediatric and family nursing, in academic and/or clinical practice, and proficiency in English. This process lasted an average of 50 days.

The experts suggested that the words of some items were translated literally from the original instrument; that some terms were further detailed; and that the most common idiomatic expressions were used. The consensual version that resulted from this committee was back-translated and sent to the author of the original version, who readily approved the back-translated version without suggesting any further changes, releasing it for semantic validation.

Semantic validation: A total of 24 parents of hospitalized children or adolescents were interviewed for the semantic validation: $91.7 \%$ were mothers and $8.3 \%$ were fathers, aged 33.3 years old on average; an average of 8.8 years of education; an average of 2.3 children; and accompanying their children at the hospital for 9.3 days on average. Homemaker was the occupation most frequently reported, with $54.2 \%$ of the participants. Most parents (95.8\%) were from the state of São Paulo, $20.8 \%$ of whom lived in Ribeirão Preto. In regard to children, $66.7 \%$ were boys and $41.7 \%$ had been hospitalized at least five times. The average age was 4.6 months, while the average time of hospitalization was 8.2 days. The diagnoses were diverse, though the most frequent ones were chronic kidney disease $(20.8 \%)$ and cancer $(20.8 \%)$.
The original instrument is self-administered; however, after the Brazilian version was applied to a sample of ten parents, difficulties were reported regarding its self-administration. Due to these difficulties, the fact it is a long instrument, and the fact that Brazilian people are not used to surveys, we opted to interview the participants. This decision was supported by the author of the original instrument. Therefore, the semantic validation was reinitiated with other parents and the researchers applied the questionnaire. Each participant took 33 minutes, on average, to complete the instrument and 10 minutes to complete the forms concerning general and specific perception of the semantic assessment. Table 1 presents the participants' responses to the general form of semantic validation.

All the participants reported they would not change anything in the instrument and $4.1 \%$ reported a desire to add something, such as items concerning the hospital's cleaning and hygiene; $12.5 \%$ did not answer at least one item for lack of understanding.

Based on specific analysis of the instrument, 37 items $(72.54 \%)$ were correctly explained by more than $80 \%$ of the participants. The other 14 items $(9,10,11,13,14,16,17,20$, $22,23,34,37,40$ and 51 ), which correspond to $27.46 \%$ of the total items, were correctly explained by less than $80 \%$ of the sample. Therefore, considering the suggestions provided by the participants, the 14 items were reformulated (Chart 1 ) and later reassessed by a group of six participants.

In the second stage of validation, using the questionnaire assessing general impressions, $33.3 \%$ of the participants considered the instrument to be good and $66.7 \%$ considered it very good; $66.6 \%$ considered the items easy to understand; while $33.3 \%$ reported that some items were difficult to understand. In regard to the use of categories of response, $83.3 \%$ denied

Table 1. Distribution of participants according to their responses to the form addressing general perceptions, Ribeirão Preto, SP, Brazil, $2016(n=24)$

\section{Items from the form concerning general impressions}

What do you think about the questions?
What do you think of the instrument in general?

Alternative of answers

$$
\text { Very good }
$$

Good

Regular/more or less

They were all easy

Some were difficult All questions were difficult

\footnotetext{
What about the categories of answer? Did you find them difficult?
}

Are the questions important for your health condition/disease (or that of your child)?

\section{Frequency of answers}

N $\%$

$10 \quad 41.7$

13

54.2

1

4.2

$11 \quad 45.8$

13

54.2

Source: Developed by the authors.

$\begin{array}{lcc}\text { No difficult } & 18 & 75.0 \\ \text { Some difficulty } & 6 & 25.0 \\ \text { Many difficulties } & - & - \\ \text { Very important } & 21 & 87.5 \\ \text { portant sometimes } & 3 & 12.5 \\ \text { Not important } & - & -\end{array}$




\begin{tabular}{|c|c|c|}
\hline Item & NPQ - before semantic analysis & NPQ - after semantic analysis \\
\hline 9 & $\begin{array}{l}\text { Que eu possa perguntar aos enfermeiros e médicos } \\
\text { sobre como explicar a doença e/ou os exames para meu } \\
\text { filho (minha filha). }\end{array}$ & $\begin{array}{l}\text { Que você possa perguntar aos médicos e enfermeiros } \\
\text { sobre como explicar ao seu filho sobre a doença dele e } \\
\text { os exames. }\end{array}$ \\
\hline 10 & $\begin{array}{l}\text { Que o trabalho na unidade onde o meu filho (minha } \\
\text { filha) estiver internado(a) seja flexível de acordo com as } \\
\text { necessidades dos pais. }\end{array}$ & $\begin{array}{l}\text { Que o trabalho dos profissionais na unidade onde seu } \\
\text { filho (sua filha) estiver internado(a) seja adaptado às } \\
\text { necessidades dos pais. }\end{array}$ \\
\hline 11 & $\begin{array}{l}\text { Ter alguém (enfermeiro ou médico) na unidade onde } \\
\text { meu filho (minha filha) está internado(a) que seja res- } \\
\text { ponsável por cuidar e atender às necessidades dos pais. }\end{array}$ & $\begin{array}{l}\text { Ter alguém (enfermeiro ou médico) na unidade onde seu } \\
\text { filho (sua filha) está internado(a) que seja responsável } \\
\text { por cuidar dos pais e ajudá-los naquilo que precisarem. }\end{array}$ \\
\hline 13 & $\begin{array}{l}\text { Que eu seja informado sobre os cuidados do meu filho } \\
\text { (minha filha) no preparo para sua alta. }\end{array}$ & $\begin{array}{l}\text { Que o(a) senhor(a) seja informado(a) sobre como deverá } \\
\text { cuidar do seu filho (sua filha) em casa quando estiverem } \\
\text { se preparando para a alta. }\end{array}$ \\
\hline 14 & $\begin{array}{l}\text { Que eu possa tomar a decisão final sobre o tratamento } \\
\text { que o meu filho (a minha filha) irá receber, depois de } \\
\text { ser informado por médicos ou enfermeiros sobre as } \\
\text { propostas de tratamentos. }\end{array}$ & $\begin{array}{l}\text { Que os enfermeiros e médicos expliquem sobre os tipos } \\
\text { de tratamento possíveis para o seu filho (sua filha) e lhe } \\
\text { deixem decidir qual será o melhor. }\end{array}$ \\
\hline 16 & $\begin{array}{l}\text { Que eu seja incentivado pela equipe de saúde a vir e } \\
\text { ficar com o meu filho (a minha filha). }\end{array}$ & $\begin{array}{l}\text { Que a equipe de saúde lhe incentive a vir ao hospital e } \\
\text { ficar junto com o seu filho (a minha filha) enquanto ele } \\
\text { (a) estiver internado(a). }\end{array}$ \\
\hline 17 & $\begin{array}{l}\text { Que um enfermeiro me ajude a reconhecer minhas } \\
\text { próprias necessidades, por exemplo, comer e dormir. }\end{array}$ & $\begin{array}{l}\text { Que um enfermeiro lhe ajude a identificar suas próprias } \\
\text { necessidades, por exemplo, comer e dormir, enquanto } \\
\text { o(a) senhor(a) estiver acompanhando seu filho (sua filha) } \\
\text { no hospital. }\end{array}$ \\
\hline 20 & $\begin{array}{l}\text { Ter uma pessoa na unidade em que meu filho (a minha } \\
\text { filha) estiver internado(a) que seja especialmente } \\
\text { responsável por cuidar das suas necessidades. }\end{array}$ & $\begin{array}{l}\text { Que na unidade onde seu filho (sua filha) estiver } \\
\text { internado(a) haja uma pessoa responsável por cuidar das } \\
\text { necessidades dele (a). }\end{array}$ \\
\hline 22 & $\begin{array}{l}\text { Que um enfermeiro (ex.: da unidade básica de saúde) } \\
\text { acompanhe o meu filho (a minha filha) após a alta, consi- } \\
\text { derando a sua saúde com base na última hospitalização. }\end{array}$ & $\begin{array}{l}\text { Que quando o seu filho (sua filha) receber alta e for para } \\
\text { casa, algum enfermeiro (ex.: do posto de saúde) continue } \\
\text { acompanhando e cuidando da saúde dele(a). }\end{array}$ \\
\hline 23 & $\begin{array}{l}\text { Que eu possa participar dos cuidados de enfermagem do } \\
\text { meu filho (da minha filha). }\end{array}$ & $\begin{array}{l}\text { Que o(a) senhor(a) possa ajudar nos cuidados de } \\
\text { enfermagem do(a) seu filho (sua filha) enquanto vocês } \\
\text { estiverem aqui no hospital. }\end{array}$ \\
\hline 34 & $\begin{array}{l}\text { Que os enfermeiros falem comigo e perguntem sobre } \\
\text { os cuidados de enfermagem necessários ao meu filho } \\
\text { (à minha filha). }\end{array}$ & $\begin{array}{l}\text { Que os enfermeiros falem com o(a) senhor(a) e } \\
\text { perguntem sobre os cuidados de enfermagem que o(a) } \\
\text { senhor(a) acha que o seu filho (sua filha) está precisando. }\end{array}$ \\
\hline 37 & $\begin{array}{l}\text { Que eu receba assistência e apoio para reconhecer } \\
\text { e entender as minhas próprias necessidades (Ex.: } \\
\text { ansiedade e cansaço). }\end{array}$ & $\begin{array}{l}\text { Que o(a) senhor(a) receba ajuda para identificar e } \\
\text { entender suas próprias necessidades (Ex.: ansiedade } \\
\text { e cansaço). }\end{array}$ \\
\hline 40 & $\begin{array}{l}\text { Sentir que sou necessário na unidade onde meu filho } \\
\text { (minha filha) está internado(a). }\end{array}$ & $\begin{array}{l}\text { Sentir que o(a) senhor(a) é importante na unidade onde } \\
\text { o(a) seu filho (sua filha) está internado(a). }\end{array}$ \\
\hline 51 & $\begin{array}{l}\text { Que um professor me ajude a estimular o meu filho } \\
\text { (a minha filha) a manter seu desenvolvimento e } \\
\text { aprendizagem. }\end{array}$ & $\begin{array}{l}\text { Que um professor lhe ajude a incentivar o(a) seu filho } \\
\text { (sua filha) a continuar se desenvolvendo e aprendendo } \\
\text { enquanto estiver internado(a). }\end{array}$ \\
\hline
\end{tabular}


any difficulty and all the participants considered the items to be very important. Two $(3.9 \%)$ out of the 51 items were correctly explained by $66.6 \%$ of the participants (less than $80 \%$ ). We also considered them valid, since the percentage of correct explanations is considerable (66\%). Therefore, the 51 items of the instrument were considered valid.

During the instrument applications, the participants reported difficulty answering subscales $B$ and $C$ when they chose the option "does not apply to your situation" in subscale A, because they had not yet experienced that type of need. This issue was presented to the instrument's author, who determined that the parents could decide whether they wanted to answer the questions in subscales $B$ and $C$, which was then clarified to the participants, along with clarifying the instrument's initial instructions.

At the end of the Semantic Validation, the last version of the instrument was back-translated and sent to the author of the original instrument, at which time we also asked her permission to use only the first part of the instrument containing 51 items addressing needs, since the other two parts were not applicable to the study's objective. In the stage concerning the instrument assessment, in addition to a low level of response on the part of the participants, similar data had been collected during the semantic validation with the specific objective of verifying opinions regarding the instrument items. In the third part, concerning the sample characterization, we opted for a sociocultural assessment questionnaire already used by the research group.

Pilot study: 65 parents were invited in this stage, but four of them interrupted the interview because they needed to take care of some issue related to their hospitalized child and did not want to continue it at another time. Two mothers were indisposed and refused to participate. Therefore, the pilot study was conducted with a sample of 59 parents of children hospitalized in the pediatric unit of the hospital selected for this study. The interviews took 39 minutes, on average.

A total of $79.7 \%$ were mothers, $11.9 \%$ were parents and $8.5 \%$ were primary caregivers with some other degree of kinship; they were aged 34 years old on average, with 8.9 years of education on average and an average of 2.4 children. On average, they had been accompanying the child for 11.8 days. In regard to marital status, $66.1 \%$ were married or were in a stable relationship, while the remainder was single, divorced or widowed. In regard to religion, $49.2 \%$ were Catholic and $35.6 \%$ were Evangelicals; $72.9 \%$ reported they were active practitioners of their religions. The most frequent occupation was homemaker, reported by $49.2 \%$ of the participants. Most parents (93.2\%) were from the state of São Paulo; $30.5 \%$ of these lived in Ribeirão Preto. In regard to the children who were hospitalized in the pediatric unit, $54.2 \%$ were girls and $45.8 \%$ were boys, while $44.1 \%$ had been hospitalized at least five times; aged 6.4 years old on average; and were hospitalized for an average of
24.6 days. The diagnoses were very diversified, however, the following predominated: Short bowel syndrome, Cystic fibrosis, Congenital heart disease, and type 1 Diabetes Mellitus, with a percentage of 5.1 each.

After double entering and analyzing data, the reliability of the instrument concerning its internal consistency was verified using Cronbach's alpha for subscales "importance" $(a=0,83)$ and "satisfaction" $(a=0.95)$, the response options of which were available in a Likert scale, while the Kuder Richardson test was applied for the subscale "independence" $(a=0.83)$, which presented a dichotomous type of answer.

\section{DISCUSSION}

Validating an existing instrument, instead of creating a new one, saves time and resources, in addition to enabling the comparison of results obtained by other studies conducted in different contexts. ${ }^{35}$ Nonetheless, in addition to being a complex process, the cultural and linguistic adaptation of an instrument requires methodological rigor so the validated instrument actually assesses what it was designed to assess. ${ }^{24,36}$ The methodological framework used in the development of this study was an adaptation of what has been recommended by the DISABKIDS $^{\circledR}$ group, a globally consolidated method. ${ }^{30,35}$ This method has strengths that differentiate it from others, such as the inclusion and operationalization of the semantic validation phase, respecting ethical issues and considering aspects that are relevant to the object of study, such as age, sex, and education. Additionally, adding the stage in which the instrument was assessed by an expert committee ${ }^{26}$ conferred greater rigor on the cultural adaptation process due to the semantic, idiomatic, conceptual and cultural equivalence.

The Needs of Parents Questionnaire (NPQ) was developed by the Icelandic author Gudrún Kristjánsdóttir ${ }^{16,17}$ and is used in various countries, such as Iceland, ${ }^{15-17}$ Sweden, ${ }^{18}$ England, ${ }^{19}$ Australia, ${ }^{20}$ Greece, ${ }^{21}$ Mozambique,${ }^{22}$ and Portugal, ${ }^{23,24}$ confirming its relevance in the international context. When its Portuguese version was used in Mozambique, the authors adopted an instrument based on the NPQ modified for the Mozambican culture. ${ }^{27}$ The aforementioned authors report the instrument was translated to Portuguese by an authorized translator and the face validity of this new version was also assessed. Subsequently, two professors, who were nurses and experts in pediatrics, and a Mozambican bilingual researcher with experience in hospital care, revised the translation and implemented some changes. A pilot test was applied to three family caregivers of hospitalized children and, even though the instrument was not changed after this step, the authors found it difficult to obtain the consent of the participants and overcome language problems.

Even though the methodological option employed by the aforementioned authors ${ }^{22}$ to conduct the cultural adaptation of the NPQ was different from the one employed in this study, 
similar results were found. Söderbäck and Christensson ${ }^{22}$ report problems regarding the language used in the questionnaire, similar to what we found in the case of Brazil, which may be related to the population's socioeconomic and educational levels, which is similar in both countries. Another aspect to be taken into account is that, similar to this study, the researchers in Mozambique also included family caregivers other than the biological parents, considering that diverse family arrangements are adopted in Brazil and Mozambique.

In the translation and adaptation process of the NPQ conducted in Portugal, ${ }^{23,24}$ some words were translated as in the Brazilian version; however, due to the cultural diversity and expressions that are inherent to each country, these versions presented significant differences in terms of vocabulary and how sentences are formulated. For instance, some sentences were synthesized in the Portuguese version, while these same sentences required more detail in the Brazilian version. It is believed that these issues are associated with different socioeconomic and educational levels found in these countries, which also differ, in addition to particularities that concern Brazilian culture and language.

In the pre-test conducted by Kristjánsdóttir, ${ }^{17}$ two parents were invited to fill out the questionnaire and comment on its structure, clarity of items, and how difficult or easy it was to complete. According to the author, the parents did not report difficulties; rather, they stated the questionnaire was easy and represented their needs well. Kyritsi and colleagues ${ }^{26}$ also found the same results in their pre-test conducted with five parents in Greece.

Shields, Kristensson-Hallström and O'Callaghan ${ }^{18}$ used the NPQ in Sweden as part of a cross-cultural study that assessed the needs of parents in Australia, Sweden and England. According to the authors, the NPQ was initially tested in English with a group of ten parents of children hospitalized in Australia, and a few changes were implemented. The instrument was then translated into Swedish and this new version was verified by a nurse proficient in English and was then tested with ten parents in Sweden and more changes were implemented. During the field study, only $1 \%$ of the participants reported difficulties understanding all or most of the instrument items. When used in England, as part of the same cross-cultural study, Shields, Hunter and Hall ${ }^{19}$ considered the pilot test conducted in Australia sufficient for the instrument to be used in England due to similarities between the English and Australian cultures.

The results of the pre-tests conducted by the aforementioned authors ${ }^{14-19}$ differ from those found in this study, since many of the participants in the phase of semantic validation in Brazil, even though they considered the statements important and representative of their condition, found it difficult to understand the structure of the instrument and the instrument items, probably due to the characteristics of the Brazilian population and low educational level in the country. ${ }^{37}$ Additionally, the aforementioned authors did not establish a minimum number of participants to be included in the pilot tests, thus the samples used may have not been sufficient to express the difficulties of populations in general.

Event though the author of the original version initially used the instrument with a sample of parents of 2- to 6-year-oldchildren, ${ }^{17}$ subsequent studies included parents of children at different ages, for instance: from 2 to 12 years old, ${ }^{15}$ from birth to 18 years old,,$^{18,20}$ from birth to 16 years old,,$^{19}$ and from 2 months to 14 years old, ${ }^{21}$ and all obtained Cronbach's alphas similar to that of the original study, showing that the instrument can be used with the parents of children in different age ranges.

Bragadottir ${ }^{15}$ reports that, only eight out of the 32 parents who took part in the field study answered all the questions in the three parts of the instrument. According to the author, many did not answer sociodemographic questions. She also noticed that when the parents chose the option "does not apply to your situation" in subscale "importance", answering subscales "satisfaction" and "independence" became irrelevant. This observation is consistent with the results found in this study during the semantic validation and pilot test, as generally, the participants report that one statement did not apply to their situation and were not capable to answer the "satisfaction" and "independence" subscales because they had not experienced that type of need.

In regard to the instrument's reliability, verified through internal consistency, the Cronbach's alphas obtained for domains $A$ and $B$ were, 0.83 and 0.95 , respectively, while the value obtained by the Kuder Richardson test for domain $C$ was 0.83 , all greater than 0.70 , as defended by Terwee and colleagues, ${ }^{34}$ which are similar to those found by the author of the original version, $0.92,0.95$ and $0.91,16,17$ ensuring the reliability of the instrument Brazilian version. Even though there are various tests to assess the psychometric properties of an instrument, this study verified the face and content validity and reliability of the NPQ adapted version in terms of internal consistency, as these are the only aspects presented by the author of the original version and by other authors who used the instrument. ${ }^{15,18-24}$ Additionally, depending on the application intended, some properties are more important than others. Therefore, the results obtained by Cronbach's alpha and the Kuder Richardson test confirms that the construct is properly represented and there is a correlation among its items.

In regard to the floor and ceiling factors, Bragadottir ${ }^{15}$ already expected asymmetry in the results of her study when she used the NPQ, as all statements of the questionnaire were based on needs already identified in previous studies as being important to the parents of hospitalized children. Therefore, it was already expected that most parents would consider most statements "very important", indicating that these effects would be relevant in this study. Bragadottir ${ }^{15}$ notes that this can be considered a limitation of the NPQ, which led to a low variation in the distribution of values. 
Shields, Hunter and Hall ${ }^{19}$ verified that, even though they used the categories of needs in the way Kristjánsdóttir ${ }^{17}$ had used them, some items seemed to be inappropriately assigned to some categories. Even though they did not present statistical data showing this inappropriateness, Shields, Hunter and Hall19 suggest that a deeper analysis of this distribution of items could reveal interesting results. In this sense, it is expected that during field study, the final stage of the validation process of the NPQ in Brazil, based on a representative sample of the target population, will enable statistical tests to better assess the instrument items and their categorization.

\section{CONCLUSIONS AND IMPLICATIONS TO PRACTICE}

This study followed the stages of translation, expert committee, back translation, semantic validation, and pilot test, inserted in a process of cultural adaptation and assessment of internal consistency of the NPQ. Face and content validity, as well as the internal consistency of the translated version adapted for Brazil, was also verified, as proposed in the objectives.

Each of these stages was performed with extreme methodological rigor, which confers credibility on this study. Its findings show that the NPQ translated version adapted for Brazil is valid and reliable for assessing the needs of parents of hospitalized children and adolescents. It is, however, necessary for this version to be tested in a representative sample of this population through a field study, so that the instrument validation process is completed and the instrument may be available for use in the Brazilian context.

Additionally, considering that the social and cultural context of Brazil may have influenced the instrument validation process due to its territorial expanse, we suggest that for the NPQ be used in other Brazilian regions, such that a new semantic validation be performed and the questionnaire adapted to the sociocultural context of the target population.

When the instrument is made available, we expect the validated Brazilian version of the NPQ to expand the possibilities for nurses and other healthcare workers to access the needs of parents of hospitalized children and adolescents, giving priority to such needs and supporting the implementation of interventions intended to meet these needs, qualifying the care delivered to this clientele.

\section{ACKNOWLEDGMENT}

We thank the Coordination for the Improvement of Higher Education Personnel (CAPES) for the financial support provided in the form of a Master's scholarship to the primary author.

\section{REFERENCES}

1. Burns-Nader S, Hernandez-Reif M, Porter M. The relationship between mothers' coping patterns and children's anxiety about their hospitalization as reflected in drawings. J Child Health Care [Internet] 2014 Mar; [cited 2015 Jan 22]; 18(1):6-18. Available from: http://chc. sagepub.com/content/18/1/6.long

2. Walker-Vischer L, Hill C, Mendez SS. The experience of latino parents of hospitalized children during family-centered rounds. J Nurs Adm [Internet]. 2015 Mar; [cited 2016 Jul 13]; 45(3):152-7. Available from: http://www.ncbi.nlm.nih.gov/pubmed/25689501

3. Feeg VD, Paraszczuk AM, Çavuşoğlu H, Shields L, Pars H, Al Mamun A. How Is Family Centered Care Perceived By Health Care Providers From Different Countries? An International Comparison. J Pediatr Nurs [Internet]. 2016 May/Jun; [cited 2016 Aug 23]; 31(3):267-76. Available from: https://www.ncbi.nlm.nih.gov/pubmed/?term=How+is+family+c entered+care+perceived+by+health+care+providers+from+different +countries\%3F+An+International+Compariso

4. Foster MJ, Whitehead L, Maybee P, Cullens V. The Parents', Hospitalized Child's, and Health Care Providers' Perceptions and Experiences of Family Centered Care Within a Pediatric Critical Care Setting. J Fam Nurs [Internet]. 2013 Jul; [cited 2017 Aug 22]; 19(4):431-68. Available from: http://journals.sagepub.com/doi/ pdf/10.1177/1074840713496317

5. Zhou H, Shields L, Watts R, Taylor M, Munns A, Ngune I. Family-centred care for hospitalized children aged 0-12 years: A systematic review of qualitative studies. JBI Libr Syst Rev. [Internet]. 2012; [cited 2015 Jan 20]; 10(57):3917-35. Available from: https://www.ncbi.nlm.nih.gov/ pubmed/27820513

6. Andrade RC, Marques AR, Leite ACAB, Martimiano RR, Santos BD, Pan R, et al. The needs of parents of hospitalized children: evidence for care. Rev Eletr Enferm [Internet]. 2015 Abr/Jun; [cited 2017 Oct 24]; 17(2):379-94. Available from: http://revistas.ufg.br/fen/article/view/30041

7. Jones J, Nowacki AS, Greene A, Traul C, Goldfarb J. Investigating Parent Needs, Participation, and Psychological Distress in the Children's Hospital. Hosp Pediatr [Internet]. 2017 Jul; [cited 2017 Aug 22]; 7(7):38594. Available from: https://www.ncbi.nlm.nih.gov/pubmed/28572146

8. Bedells E, Bevan A. Roles of nurses and parents caring for hospitalized children. Nurs Child Young People [Internet]. 2016 Mar; [cited 2017 Jan 20]; 28(2):24-8. Available from: https://www.ncbi.nlm.nih.gov/ pubmed/26954646

9. Davies R. Marking the 50th anniversary of the Platt Report: from exclusion, to toleration and parental participation in the care of the hospitalized child. J Child Health Care [Internet]. 2010 Mar; [cited 2015 Jan 20]; 14(1):6-23. Available from: https://www.ncbi.nlm.nih.gov/pub $\mathrm{med} /$ ?term=Marking+the+50th+anniversary+of+the+Platt+Report\% $3 \mathrm{~A}+$ from+exclusion $\% 2 \mathrm{C}+$ to+toleration+and+parental+participation+i $\mathrm{n}+$ the+care+of+the+hospitalized+child

10. Ministry of Health. Central Health Services Council. The Welfare of Children in Hospital. (The Platt Report). London: Her Majesty's Stationery Office; 1959.

11. Ministério da Saúde (BR). Estatuto da Criança e do Adolescente. $3^{a}$ ed Brasília (DF): Ministério da Saúde; 2008. Available from: http://bvsms. saude.gov.br/bvs/publicacoes/estatuto_crianca_adolescente_3ed.pdf

12. Majdalani MN, Doumit MA, Rahi AC. The lived experience of parents of children admitted to the pediatric intensive care unit in Lebanon. Int J Nurs Stud [Internet]. 2014 Feb; [cited 2015 Jul 24]; 51(2):21725. Available from: http://www.sciencedirect.com/science/article/pii/ S002074891300182X

13. Streiner DL, Kottner J. Recommendations for reporting the results of studies of instrument and scale development and testing. J Adv Nurs [Internet]. 2014 Sep; [cited 2015 Feb 13]; 70(9):1970-9. Available from: http://onlinelibrary.wiley.com/doi/10.1111/jan.12402/abstract 
14. McClimans L, Browne J, Cano S. Clinical outcome measurement: Models, theory, psychometrics and practice. Stud Hist Philos Biol Biomed Sci [Internet]. 2017 Jul; [cited 2017 Aug 22]; 1-7. In press. Available from: http://dx.doi.org/10.1016/j.shpsa.2017.06.004

15. Bragadóttir H. A descriptive study of the extent to which self-perceived needs of parents are met in paediatric units in Iceland. Scand $\mathrm{J}$ Caring Sci [Internet]. 1999; [cited 2014 Jul 23]; 13(3):201-7. Available from: https://www.ncbi.nlm.nih.gov/pubmed/12033126

16. Kristjánsdóttir G. A study of the needs of parents of hospitalized 2- to 6-year-old children. Issues Compr Pediatr Nurs [Internet]. $1991 \mathrm{Jan} /$ Mar; [cited 2014 Jul 23]; 14(1):49-64. Available from: https://www.ncbi. nlm.nih.gov/pubmed/?term=A+Study+of+the+Needs+of+Parents+of+ Hospitalized+2-to+6-Year-Old+Children

17. Kristjánsdóttir G. Perceived importance of needs expressed by parents of hospitalized two- to six-year-olds. Scand J Caring Sci [Internet]. 1995 Jun; [cited 2014 Jul 23]; 9(2):95-103. Available from: http://onlinelibrary. wiley.com/doi/10.1111/j.1471-6712.1995.tb00394.x/abstract

18. Shields L, Kristensson-Hallström I, O'Callaghan M. An examination of the needs of parents of hospitalized children: comparing parents' and staff's perceptions. Scand J Caring Sci [Internet]. 2003 Jun; [cited 2015 Jan 22]; 17(2):176-84. Available from: http://onlinelibrary.wiley.com/ doi/10.1046/j.1471-6712.2003.00215.x/abstract

19. Shields L, Hunter J, Hall J. Parents' and staff's perceptions of parental needs during a child's admission to hospital: an English perspective. J Child Health Care [Internet]. 2004 Mar; [cited 2015 Jan 22]; 8(1):9-33. Available from: http://chc.sagepub.com/content/8/1/9.long

20. Shields L, Young J, McCann D. The needs of parents of hospitalized children in Australia. J Child Health Care [Internet]. 2008 Mar; [cited 2015 Jan 22]; 12(1):60-75. Available from: http://chc.sagepub.com/ content/12/1/60.long

21. Kyritsi H, Matiziou V, Perdikaris P, Evagelou H. Parents' needs during their child's hospitalization. Nursing Gr. 2005; [cited 2015 Jan 22]; 23:1-9.

22. Söderbäck M, Christensson K. Family involvement in the care of a hospitalised child: a questionnaire survey of Mozambican family caregivers. Int J Nurs Stud [Internet]. 2008 Dec; [cited 2015 Jan 22]; 45(12): 1778-88. Available from: https://www.ncbi.nlm.nih.gov/pubmed/?term=Family+in volvement+in+the+care+of+a+hospitalized+child\%3A+a+questionnair e+survey+of+Mozambican+family+caregivers

23. Ferreira PL, Melo E, Reis G, Mello DF. Validação e análise da precisão da versão em português do Needs of Parents Questionnaire. J Pediatr [Internet]. 2010 Jun; [cited 2016 Oct 19]; 86(3):221-7. Available from: http://www.scielo.br/scielo.php?script=sci_arttext\&pid=S0021$75572010000300010 \& \operatorname{lng}=\mathrm{en}$

24. Reis GMR. Expectativas dos pais durante a hospitalização da criança [dissertação]. Porto: Universidade do Porto; 2007.

25. Disabkids ${ }^{\circledR}$ Group. The Kidscreen/Disabkids ${ }^{\circledR}$ Project; 2015. [cited 2015 Mar 14]. Available from: http://www.disabkids.de

26. Guillemin F, Bombardier C, Beaton D. Cross-cultural adaptation of health-related quality of life measures: Literature review and proposed guidelines. J Clin Epidemiol [Internet]. 1993 Dec; [cited 2013 Aug 10]; 46(12):1417-32. Available from: http://www.sciencedirect.com/science/ article/pii/089543569390142N
27. Beaton DE, Bombardier C, Guillemin F, Ferraz MB. Guidelines for the process of cross-cultural adaptation of self-report measures. Spine (Phila Pa 1976) [Internet]. 2000 Dec 15; [cited 2013 Aug 10]; 25(24):3186-91. Available from: https://www.ncbi.nlm.nih.gov/pubmed/11124735

28. Pasquali L. Psicometria. Rev Esc Enferm [Internet]. 2009 Dec; [cited 2016 Jan 15]; 43(no.spe):992-9. Available from: http://dx.doi.org/10.1590/ S0080-62342009000500002

29. Fegadolli C, Reis RA, Martins STA, Bullinger M, Santos CB. Adaptation of the generic DISABKIDS ${ }^{\circledR}$ module for Brazilian children and adolescents with chronic disorders. Rev Bras Saúde Mater Infant [Internet]. 2010 Jan/Mar; [cited 2016 Jan 15]; 10(1):95-105. Available from: http://dx.doi. org/10.1590/S1519-38292010000100010

30. DISABKIDS ${ }^{\circledR}$ Group. Translation and validation procedure: guidelines and documentation form. Leiden:The DISABKIDS ${ }^{\circledR}$ Group; 2004. [cited 2016 Jan 15]. Available from: https://www.disabkids.org/licensing-anduse/validation-guidelines/

31. Sapnas KG, Zeller RA. Minimizing sample size when using exploratory factor analysis for measurement. J Nurs Meas [Internet]. 2002 Fall; [cited 2015 Jan 22]; 10(2):135-54. Available from: https://www.ncbi.nlm.nih. gov/pubmed/12619534

32. Fayers PM, Machin D. Quality of life: the assessment, analysis, and interpretation of patient-reported outcomes. 2nd ed. New York: John Wiley \& Sons; $2007.544 \mathrm{p}$.

33. Dias AS, Vendramini CMM. Full information Factorial Analysis of a Reading Comprehension Test in Statistics. Psicol Esc Educ [Internet] 2008 Dec; [cited 2014 Jul 13]; 12(2):357-67. Available from: http://dx.doi. org/10.1590/S1413-85572008000200007

34. Terwee CB, Bot SD, de Boer MR, van der Windt DA, Knol DL, Dekker $J$, et al. Quality criteria were proposed for measurement properties of health status questionnaires. J Clin Epidemiol. [Internet]. 2007 Jan [cited 2016 Jan 29]; 60(1):34-42. Available from: https://www.ncbi.nlm. nih.gov/pubmed/17161752

35. Poli-Neto OB, Chama PPF, Romão APMS, Dantas RAS, Rosa-eSilva JC, Candido-dos-Reis FJ, et al. Cultural Adaptation of the Patient Satisfaction Questionnaire and Validation of Its Use in the Portuguese Language for Women with Chronic Pelvic Pain. Rev Bras Ginecol Obstet [Internet]. 2016 Sep; [cited 2017 Aug 22] 38(9):443-9. Available from: http://www.scielo.br/scielo.php?script=sci arttext\&pid=S0100-72032016000900443\&lng=en. http://dx.doi. org/10.1055/s-0036-1592344

36. Sousa VD, Rojjanasrirat W. Translation, adaptation and validation of instruments or scales for use in cross-cultural health care research: a clear and user-friendly guideline. J Eval Clin Pract [Internet]. 2011 Apr; [cited 2017 Oct 24]; 17(2):268-74. Available from: https://www.ncbi.nlm. nih.gov/pubmed/20874835

37. Instituto Brasileiro de Geografia e Estatística (BR). Educação: Brasil em síntese. Brasil, 2007-2014. Rio de Janeiro: IBGE; 2016 [cited 2017 Oct 25]. Available from: http://brasilemsintese.ibge.gov.br/educacao.html 